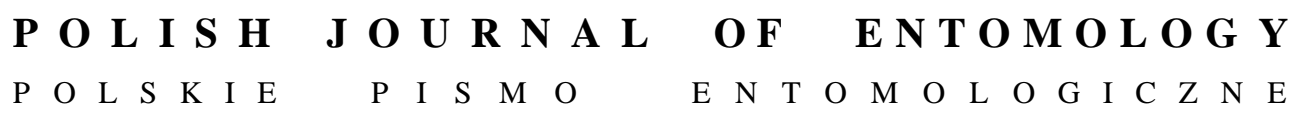

VOL. 83: 281-294

Lublin

31 December 2014

DOI: $10.2478 /$ pjen-2014-0022

\title{
Biochemical characterisation of $\alpha$-glucosidase and $\beta$-glucosidase in the alimentary canal of larval Leptinotarsa decemlineata SAY, 1824 \\ (Coleoptera: Chrysomelidae)
}

\author{
MAJID KAZZAZI ${ }^{1}$, FAHIMEH DEHGHANIKHAH ${ }^{1}$, HOSSEIN MADADI $^{1}$, \\ VAHID HOSSSEININAVEH ${ }^{2}$ \\ ${ }^{1}$ Department of Plant Protection, College of Agriculture, University of Hamedan, Iran, \\ e-mail:mkazzazi@basu.ac.ir, f.dehghanikhah@gmail.com,hmadadi@basu.ac.ir \\ ${ }^{2}$ Department of Plant Protection, College of Agriculture, University of Tehran, Karaj, Iran, \\ e-mail: vnaveh@ut.ac.ir
}

\begin{abstract}
Host plant resistance is an environmentally safe method used for reducing a pest population. Basically, when developing resistant cultivars one needs to study the biochemical characteristics of the digestive enzymes in the insect's midgut. In this study, the activities of $\alpha$ - and $\beta$-glucosidase were determined from Leptinotarsa decemlineata midgut using p-nitrophenyl- $\alpha-\mathrm{D}$ glucopyranoside and p-nitrophenyl- $\beta$-D-glucopyranoside as substrates respectively. The results showed that the specific activity of $\alpha$ - and $\beta$-glucosidase from $4^{\text {th }}$ instar larvae midguts of L. decemlineata were 5.14 and $5.48 \mathrm{Umg}^{-1}$ protein respectively. The activity of $\alpha$-glucosidase was optimal at $\mathrm{pH} 4$, whereas the maximum activity of $\beta$-glucosidase in the midgut of $L$. decemlineata occurred at $\mathrm{pH} 4-5.5$. Both enzymes were stable at $\mathrm{pH}$ 3-8 over an incubation time of 8 hours. The respective activities of $\alpha$ - and $\beta$-glucosidase were at their highest at $45{ }^{\circ} \mathrm{C}$ and $50{ }^{\circ} \mathrm{C}$, but they were not stable at $50{ }^{\circ} \mathrm{C}$ during an incubation time of 8 days. Furthermore, our data showed that $\mathrm{MgCl}_{2}$, Tris and urea have a moderate but SDS a severe inhibitory effect on enzyme activity. Biochemical characterisation revealed one and three bands of $\alpha$ - and $\beta$-glucosidase activities in the midgut of L. decemlineata respectively.
\end{abstract}

KEY WORDS: $\alpha$-glucosidase, $\beta$-glucosidase, alimentary canal, Colorado potato beetle. 


\section{INTRODUCTION}

One of the most destructive pest of the potato, the Colorado potato beetle (CPB) Leptinotarsa decemlineata SAY, 1824 seriously threatens potato production in many parts of the world (HARE 1990, CAPINERA 2001). To date, one effective way of reducing the population of this pest is to apply pesticides. However, excessive use of insecticides has led to the development of resistance in CPB to all currently registered insecticides (GAUTHIER et al. 1981, FORGASH 1985, ARGENTINE et al. 1989, HARE 1990) to such an extent that this pest is one of the top 16 resistant arthropods of the world: its resistance to 48 different active ingredients has been reported (ONSTAD 2007). Therefore, alternative control methods such as resistant or tolerant potato varieties are needed for implementing sustainable management programmes.

Glucosides are important secondary plant metabolites: digestive enzymes in an insect's midgut convert them into toxic aglycones, thereby defending plants against herbivore attacks (WEI et al. 2007). These plant metabolites could be used in genetic engineering techniques to produce plants resistant to herbivores. (MATTIACCI et al. 1995). Studying the biochemical characteristics of the CPB's digestive enzymes is a necessary prerequisite for developing cultivars resistant to CPB (RAZAVI TABATABAEI et al. 2011).

$\alpha$-Glucosidase (EC 3.2.1.20) and $\beta$-glucosidase (EC 3.2.1.21) are enzymes whose main role is played out in the terminal digestion of carbohydrate in an insect's midgut (TERRA \& FERREIRA 1994).

$\alpha$-Glucosidase catalyses the hydrolysis of $\alpha$-1,4-linked glucose residues and $\beta$-glucosidase breaks di- and oligosaccharides by attacking the terminal, non-reducing $\beta$-1,4-linked glucose residues (TERRA \& FERREIRA 1994). Additionally, $\beta$-glucosidase is an enzyme widely present in the majority of animals, plants, fungi, bacteria and other living organisms (Esen 1993). These compounds are involved in plant resistance to herbivorous insect pests. The majority of these compounds are L-glycosides that release cyanide (or other toxic compounds) upon hydrolysis that are toxic to many herbivorous insects (TERRA et al. 1996).

The purification of $\alpha$ - and $\beta$-glucosidase and studies of their enzymatic activity under different conditions have been done on many different insect species (SANTOS \& TERRA 1985, PrATVIEL et al. 1987, MARANA et al. 1995, Silva et al. 1999, MARANA et al. 2000, PONTOH \& LOW 2002, TOKUDA et al. 2002, AZEVEDO et al. 2003, CARNEIRO et al. 2004, BYEON et al. 2005, SOUZA-NETO et al. 2007, RAMZI \& HosSEININAVEH 2010, RAZAVI TABATABAEI et al. 2011). Considering the importance of carbohydrases and the study of carbohydrate digestion as a target for L. decemlineata control, the aim of this study is to provide information about some biochemical properties of $\alpha$ - and $\beta$-glucosidase extracted from the midgut of $L$. decemlineata in order to acquire a better understanding of the 
digestive physiology of the CPB.

\section{MATERIAL AND METHODS}

\section{Sample preparation}

Fourth-instar larvae of $L$. decemlineata were collected by sweep-netting around the village of Dehpiaz near the city of Hamedan, Iran, and transferred to the laboratory. They were kept on potato leaves under laboratory controlled conditions (temperature $26{ }^{\circ} \mathrm{C} \pm 1$ and photoperiod 14:10 light:dark cycle).

Prior to the experiments it was necessary to provide enzyme samples. Therefore, L. decemlineata larvae were immobilised on ice, after which their midguts were removed under a stereomicroscope. After dissection, the midguts were kept in $1 \mathrm{ml}$ doubly-distilled water. Thereafter, they were homogenised in a pre-cooled hand-held glass homogeniser. The homogenates were then centrifuged at $15000 \mathrm{~g}$ for $10 \mathrm{~min}$ at $4{ }^{\circ} \mathrm{C}$ and the supernatant stored at $-20^{\circ} \mathrm{C}$ until use (SILVA et al. 1999).

\section{Protein determination and enzyme assays}

The protein concentration was determined according to BRADFORD's (1976) method, using ovalbumin as a standard. The activities of $\alpha$ - and $\beta$-glucosidase were determined using p-nitrophenyl- $\alpha$-D-glucopyranoside and p-nitrophenyl- $\beta$-D-glucopyranoside as substrate respectively. For the $\alpha$-glucosidase assay, $10 \mu \mathrm{l}$ of the gut extract were mixed with $300 \mu \mathrm{l}$ of $40 \mathrm{mM}$ citrate-phosphate buffer at $\mathrm{pH} 4$. This mixture was then incubated after the addition of $15 \mathrm{mM}$ p-nitrophenyl- $\alpha$-D-glucopyranoside at $45{ }^{\circ} \mathrm{C}$ for $15 \mathrm{~min}$. For the $\beta$-glucosidase assay, $10 \mu \mathrm{l}$ of the gut extract were mixed with $300 \mu \mathrm{l}$ of $40 \mathrm{mM}$ citratephosphate buffer at $\mathrm{pH}$ 5. The mixture was then incubated after the addition of $15 \mathrm{mM} \mathrm{p}$ nitrophenyl- $\beta$-D-glucopyranoside at $50{ }^{\circ} \mathrm{C}$ for $15 \mathrm{~min}$. The reactions were stopped by the addition of $700 \mu \mathrm{l} \mathrm{NaOH}(2 \mathrm{M})$; the absorbance was measured at $405 \mathrm{~nm}$ after 10 minutes. One unit of enzyme activity (U) is defined as the amount that hydrolyses $1 \mathrm{mmol}$ of substrate per minute.

\section{Effect of $\mathbf{p H}$ and temperature on enzyme activities and stabilities}

The optimal $\mathrm{pH}$ for enzyme activities was measured using $300 \mu \mathrm{l} 40 \mathrm{mM}$ citratephosphate buffer with $\mathrm{pH}$ set to 2-8 at 0.5 intervals. The enzyme samples were incubated in citrate phosphate buffers at different pHs for 2 and 8 hours. The residual activities of the treated enzyme samples were measured according to the "Enzyme assay" section.

To determine the optimum temperature for the enzyme activities, the reaction mixtures were incubated at different temperatures from 5 to $70{ }^{\circ} \mathrm{C}$ at $5{ }^{\circ} \mathrm{C}$ intervals for 35 minutes 
followed by the "Enzyme assay". Enzyme stabilities were measured at 5, 26 and $50{ }^{\circ} \mathrm{C}$ for 1 to 8 days. Thereafter, the residual activities of the enzymes were determined (PARRY et al. 1996).

\section{Influence of activators and inhibitors on $\alpha$ - and $\beta$-glucosidase activities}

To test the effects of different ions on the enzyme activities, different concentrations of the chlorides of $\mathrm{Na}^{+}(5,10,20$ and $40 \mathrm{mmol} / \mathrm{l}), \mathrm{K}^{+}(5,10,20$ and $40 \mathrm{mmol} / \mathrm{l}), \mathrm{Ca}^{2+}(5,10$, 20 and $40 \mathrm{mmol} / \mathrm{l})$ and $\mathrm{Mg}^{2+}(5,10,20$ and $40 \mathrm{mmol} / \mathrm{l})$, as well as sodium dodecylsulphate (SDS, $1 \mathrm{mmol} / \mathrm{l})$, Tris $(10$ and $20 \mathrm{mmol} / \mathrm{l})$ and urea $(0.4$ and $0.8 \mathrm{~mol} / \mathrm{l})$ were added to the assay mixtures, after which the residual enzyme activities were determined following standard assay conditions.

\section{Electrophoresis}

Electrophoretic analysis was performed under native-PAGE conditions. The samples were combined with a sample buffer lacking $\beta$-mercaptoethanol and SDS $(2.1 \mathrm{ml}$ distilled water $+0.5 \mathrm{ml} 0.5 \mathrm{M}$ Tris- $\mathrm{HCl}, \mathrm{pH} 6.8+0.4 \mathrm{ml}$ glycerol $+0.2 \mathrm{ml} 1 \%(\mathrm{w} / \mathrm{v})$ bromophenol blue).

Electrophoresis was performed on $10 \%(\mathrm{w} / \mathrm{v})$ and $7.5 \%(\mathrm{w} / \mathrm{v})$ resolving polyacrylamide gels for $\alpha$ - and $\beta$-glucosidase respectively (LAEMMLI 1970) at $110 \mathrm{~V}$ without boiling the samples. In accordance with native-PAGE, the gel was washed in $40 \mathrm{mM}$ citrate phosphate buffer $\mathrm{pH} 5$ (optimal $\mathrm{pH}$ of enzyme activity) at room temperature for $20 \mathrm{~min}$. Then, the gel was incubated in this buffer containing $8 \mathrm{mM}$ fluorogenic substrate 4-methylumbelliferyl$\alpha$-D-glucoside for $\alpha$-glucosidase and 4-methylumbelliferyl- $\beta$-D-glucoside for $\beta$-glucosidase at $40{ }^{\circ} \mathrm{C}$ for 30 minutes. Finally, the $\alpha$ - and $\beta$-glucosidase activities were detected by fluorescence under UV illumination and the fluorescent bands were photographed.

\section{Statistical analysis}

The significant differences among treatments in a complete randomised design were checked by one-way analysis of variance (Anova) and means were compared using Duncan's multiple range test at the 0.05 significance level.

\section{RESULTS}

\section{$\alpha$ - and $\beta$-glucosidase activities}

$\alpha$ - and $\beta$-glucosidase activities were detected in the larval midgut of $L$. decemlineata. The specific activities of $\alpha$ - and $\beta$-glucosidase in the midgut were 5.14 and $5.48 \mathrm{Umg}^{-1}$ proteins, respectively. 


\section{Effect of $\mathrm{pH}$ and temperature on $\boldsymbol{\alpha}$ - and $\boldsymbol{\beta}$-glucosidase activities}

The effect of $\mathrm{pH}$ on $\alpha$ - and $\beta$-glucosidase activities towards $\mathrm{pN \alpha G}$ and $\mathrm{pN} \beta \mathrm{G}$ as substrate respectively were measured using $40 \mathrm{mM}$ citrate phosphate buffers ( $\mathrm{pH} 2-8$ ). The maximum activity of $\alpha$-glucosidase was determined at $\mathrm{pH} 4$, whereas the highest $\beta$-glucosidase activity in the midgut of $L$. decemlineata was obtained at $\mathrm{pH} 4$ to $\mathrm{pH} 5.5$. $\alpha$ - and $\beta$-Glucosidase activities in the midgut increased steadily from $\mathrm{pH} 2$ to 4 and then decreased with $\mathrm{pH}$ increasing from 5 to 8 for $\alpha$-glucosidase and from 6 to 8 for $\beta$-glucosidase (Fig. 1).

Both of these enzymes were stable at $\mathrm{pH} 3-8$ but not at $\mathrm{pH} 2$. Furthermore, $\alpha$ - and $\beta$-glucosidase activities increased steadily with temperatures rising from 10 to $45^{\circ} \mathrm{C}$ and 50 ${ }^{\circ} \mathrm{C}$ respectively. At temperatures above $45{ }^{\circ} \mathrm{C}$ and $50{ }^{\circ} \mathrm{C}$, the enzyme activities gradually decreased (Fig. 2).

The stability of the enzymes at different $\mathrm{pH}$ for 2 and 8 hours is shown in Figure 3. The relative activities of $\alpha$ - and $\beta$-glucosidase exhibit a similar trend in this figure at different $\mathrm{pH}$ for 2 and 8 hours' incubation.

Both enzymes are unstable at $50{ }^{\circ} \mathrm{C}$; they lost about $70 \%$ of their maximum activities after 2 days' incubation because of heat inactivation (Fig. 4).

\section{Effect of activators and inhibitors on $\alpha$ - and $\beta$-glucosidase activities}

The results showed that $\mathrm{MgCl}_{2}$, Tris and urea have a moderate inhibitory effect, whereas SDS has a severe inhibitory effect on $\alpha$ - and $\beta$-glucosidase activities. Different concentrations of $\mathrm{CaCl}_{2}$ increased midgut $\alpha$-glucosidase activity whereas the same concentration reduced $\beta$-glucosidase activity. $\mathrm{NaCl}$ and $\mathrm{KCl}$ did not have any effect on $\alpha$ - or $\beta$-glucosidase activities (Table 1).

\section{Electropherogram analyses}

The results showed single and three distinct $\alpha$ - and $\beta$-glucosidase activity bands respectively in the midgut homogenates of $4^{\text {th }}$ instar larvae of $L$. decemlineata obtained using native-PAGE (Fig. 5).

\section{DISCUSSION}

Glucosidases are enzymes that are essential for the metabolism and terminal phase of insect carbohydrate digestion. In this study, glucosidase activities were found in the midgut of $L$. decemlineata; this is to be expected in view of the CPB's feeding regime. This finding is coincident with the presence of $\alpha$ - and $\beta$-linked oligosaccharides in the CPB's diet. 

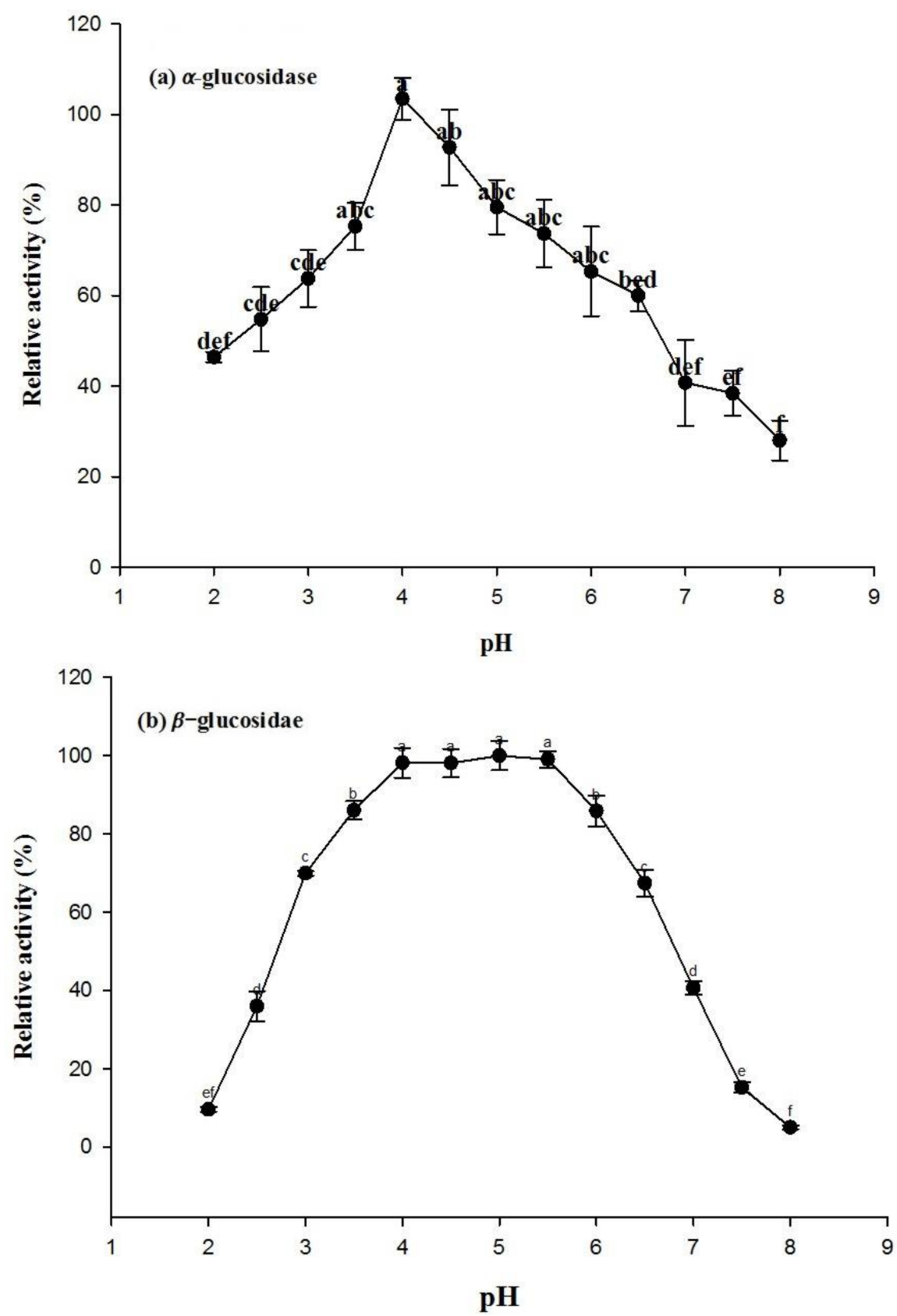

Fig. 1. Effect of $\mathrm{pH}$ on activity of $\alpha$-glucosidase (a) and $\beta$-glucosidase (b) extracted from the midgut of $L$. decemlineata. The different letters indicate that the enzyme activities are significantly different from each other $(\mathrm{p}<0.05)$. 

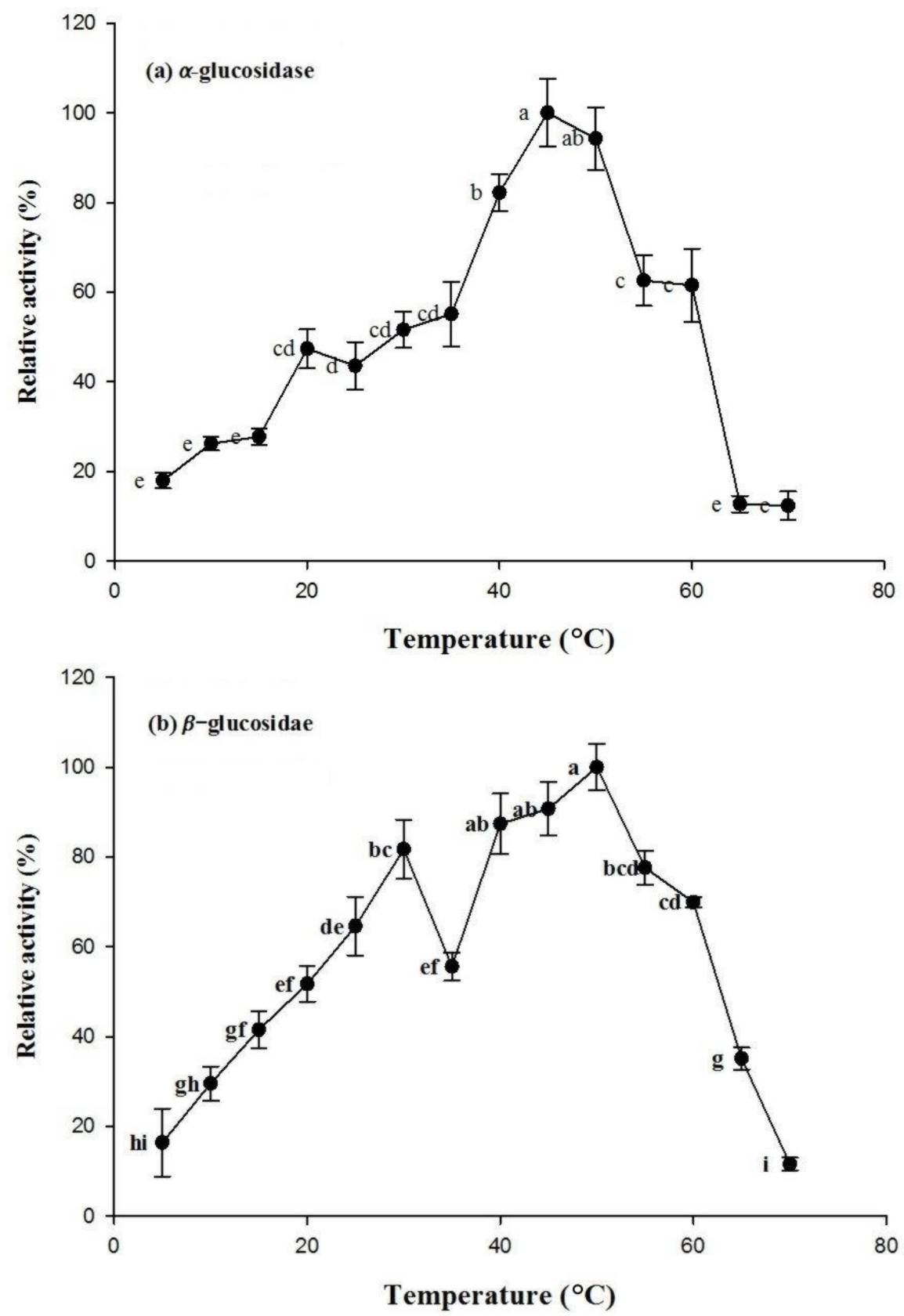

Fig. 2. Effect of temperature on the activity of $\alpha$-glucosidase (a) and $\beta$-glucosidase (b) extracted from the midgut of L. decemlineata. 

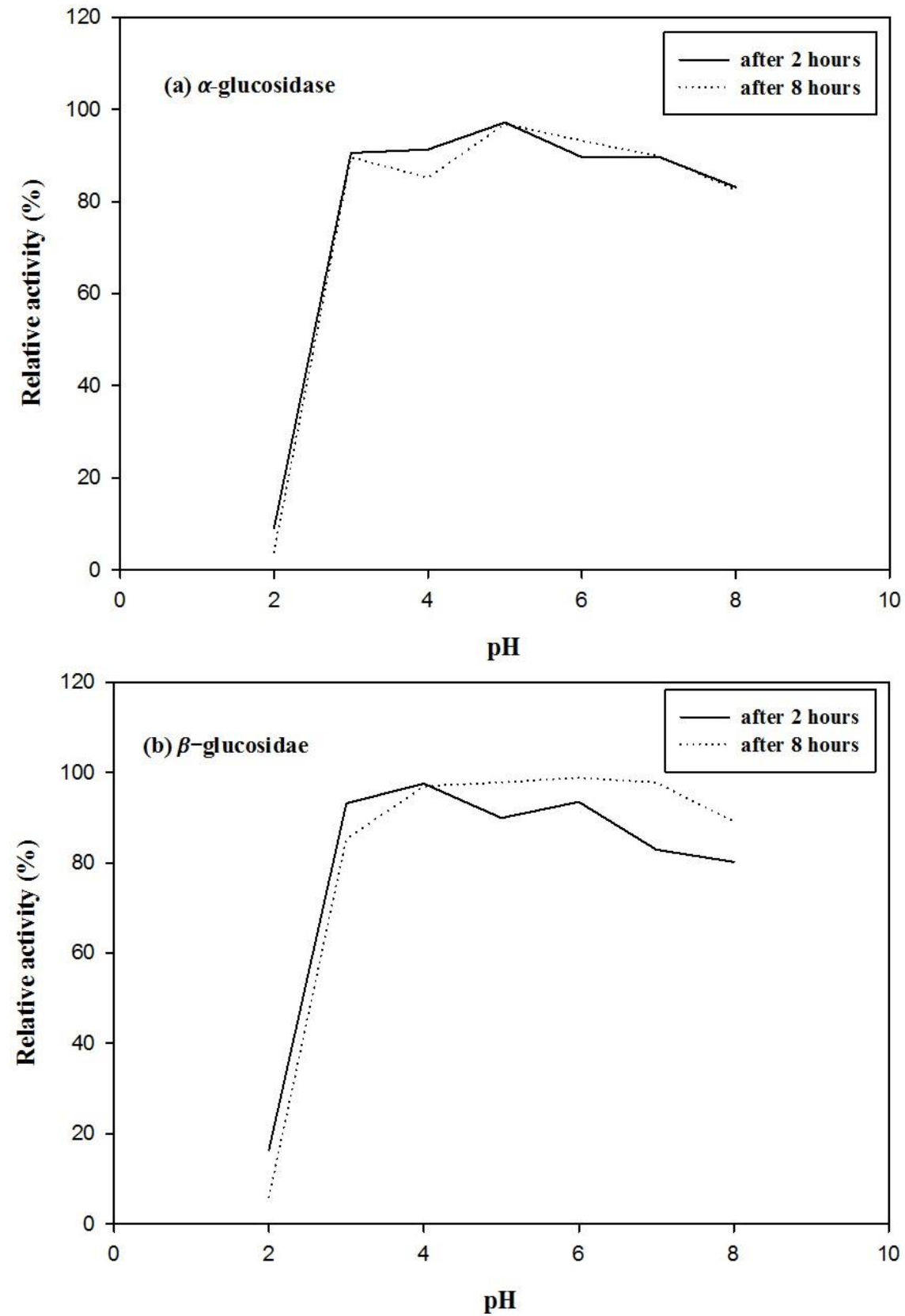

Fig. 3. Effect of $\mathrm{pH}$ on the stability of $\alpha$-glucosidase (a) and $\beta$-glucosidase (b) extracted from the midgut of L. decemlineata after 2 and 8 hours. 

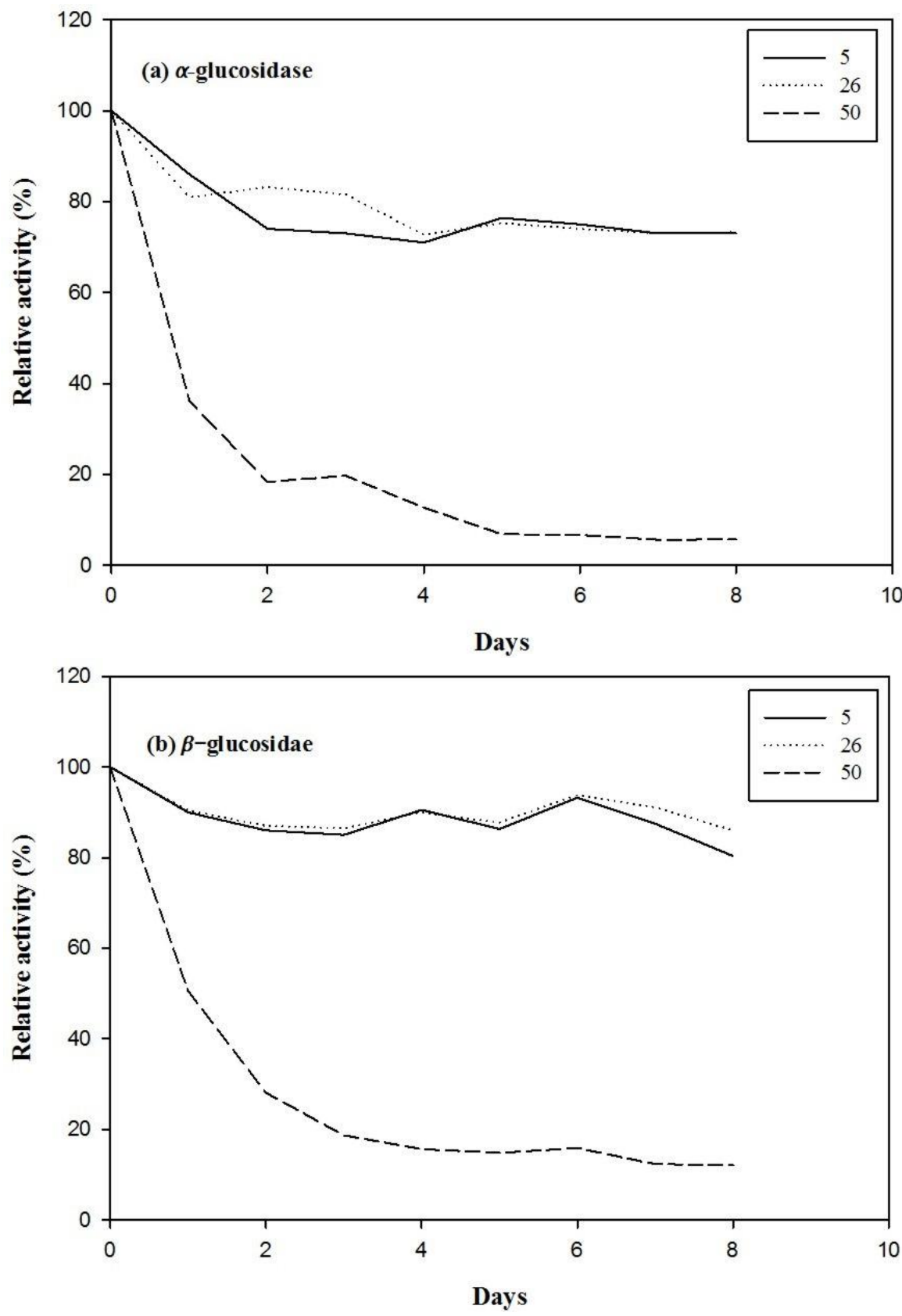

Fig. 4. Effect of temperature on the stability of $\alpha$-glucosidase (a) and $\beta$-glucosidase (b) extracted from the midgut of $L$. decemlineata (during 8 days). 


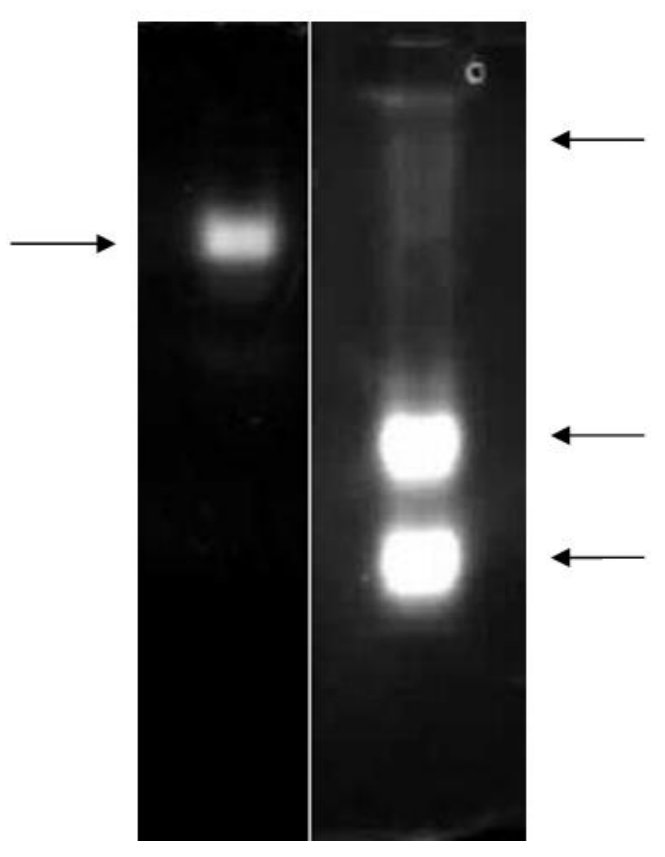

Fig. 5. Electropherogram analysis of $\alpha$-glucosidase (a) and $\beta$-glucosidase (b) activity in the midgut of the fourth larval instar of L. decemlineata.

Our results demonstrated that $\alpha$ - and $\beta$-glucosidase reach their maximum activity at acidic pHs, which is consistent with the hypothesis that there is a correlation between the pH optima of enzymes and the luminal pH of an insect's gut (TERRA \& FERREIRA 1994). Furthermore, there are no significant differences between their activities at pHs from 4 to 6 , although the curves showed different trends. Likewise, the maximum activities of midgut $\alpha$ - and $\beta$-glucosidase were obtained in most insects at acidic pHs (TERRA et al. 1985, TERrA et al. 1988, BAKER 1991, PONTOH \& LOW 2002, TOKUDA et al. 2002, BYEON et al. 2005, SouZA-NeTO et al. 2007). In our experiment $\alpha$ - and $\beta$-glucosidase exhibited a broad $\mathrm{pH}$ stability. Such a broad temperature and $\mathrm{pH}$ stability range were previously reported in other insect species (TOKUDA et al. 2002, PONTOH \& LOW 2002, BYEON et al. 2005, YAPI et al. 2009).

It was shown that $\alpha$ - and $\beta$-glucosidase reach their maximum activity at $45{ }^{\circ} \mathrm{C}$ and 50 ${ }^{\circ} \mathrm{C}$ respectively, as the protein structures of the enzymes have their optimal activities within a certain temperature range. Higher temperatures reduce enzyme activity as a result of heat inactivation (PRICE \& STEVENS 1989). Additionally, $\beta$-glucosidase was not stable above $55-60{ }^{\circ} \mathrm{C}$ because it is irreversibly inactivated, although it does display its maximum catalytic activity at $50-55^{\circ} \mathrm{C}$ (ESEN 1992). 
Table 1. Relative activity (\%) of $L$. decemlineata $\alpha$ - and $\beta$-glucosidase in the presence of different compounds.

\begin{tabular}{|c|c|c|c|}
\hline Compounds & $\begin{array}{c}\text { Concentration } \\
(\mathbf{m m o l} / \mathrm{L})\end{array}$ & $\begin{array}{c}\text { Relative activity }(\%) \\
\text { a-glucosidase }\end{array}$ & $\begin{array}{c}\text { Relative activity }(\%) \\
\beta \text {-glucosidase }\end{array}$ \\
\hline Control & - & 100 & 100 \\
\hline $\mathrm{NaCl}$ & $\begin{array}{c}5 \\
10 \\
20 \\
40\end{array}$ & $\begin{array}{c}94 \pm 0.07 \\
107 \pm 0.04 \\
97 \pm 0.05 \\
98 \pm 0.16\end{array}$ & $\begin{array}{l}98 \pm 0.11 \\
92 \pm 0.02 \\
96 \pm 0.03 \\
93 \pm 0.11\end{array}$ \\
\hline $\mathrm{KCl}$ & $\begin{array}{c}5 \\
10 \\
20 \\
40\end{array}$ & $\begin{array}{c}93 \pm 0.07 \\
96 \pm 0.07 \\
90 \pm 0.03 \\
101 \pm 0.18 \\
\end{array}$ & $\begin{array}{l}90 \pm 0.09 \\
89 \pm 0.04 \\
94 \pm 0.02 \\
95 \pm 0.01\end{array}$ \\
\hline $\mathrm{CaCl}_{2}$ & $\begin{array}{c}5 \\
10 \\
20 \\
40 \\
\end{array}$ & $\begin{array}{l}88 \pm 0.04 \\
89 \pm 0.14 \\
95 \pm 0.06 \\
97 \pm 0.14 \\
\end{array}$ & $\begin{array}{l}76 \pm 0.01 \\
65 \pm 0.04 \\
61 \pm 0.05 \\
61 \pm 0.01\end{array}$ \\
\hline $\mathrm{MgCl}_{2}$ & $\begin{array}{c}5 \\
10 \\
20 \\
40 \\
\end{array}$ & $\begin{array}{l}81 \pm 0.02 \\
79 \pm 0.14 \\
70 \pm 0.04 \\
73 \pm 0.01 \\
\end{array}$ & $\begin{array}{l}73 \pm 0.01 \\
75 \pm 0.07 \\
65 \pm 0.04 \\
49 \pm 0.01 \\
\end{array}$ \\
\hline Urea & $\begin{array}{l}400 \\
800 \\
\end{array}$ & $\begin{array}{l}84 \pm 0.16 \\
79 \pm 0.09\end{array}$ & $\begin{array}{l}73 \pm 0.07 \\
59 \pm 0.11\end{array}$ \\
\hline Tris & $\begin{array}{l}10 \\
20\end{array}$ & $\begin{array}{l}65 \pm 0.10 \\
41 \pm 0.09\end{array}$ & $\begin{array}{l}82 \pm 0.03 \\
59 \pm 0.03\end{array}$ \\
\hline SDS & 1 & $7 \pm 0.01$ & $5 \pm 0.01$ \\
\hline
\end{tabular}

The present study also implies that divalent cations reduce the activities of $\alpha$ - and $\beta$-glucosidase. Many glycohydrolases are inhibited by divalent cations. These cations change the structure of the protein and reduce enzyme activity (BOWERS et al. 2007). However, there are also several glycohydrolases in insects that are activated by cations, such as $\alpha$-amylase by $\mathrm{Ca}^{+2}$ (TERRA \& FERREIRA 1994) and $\alpha$-glucosidase by $\mathrm{Ca}^{+2}$ (GHADAMYARI et al. 2010). In addition, insect $\alpha$-glucosidase is strongly inhibited by Tris (TERRA \& FERREIRA 1994).

The electropherogram analysis of the $L$. decemlineata midgut showed single and three distinct bands for $\alpha$ - and $\beta$-glucosidase respectively. In previous studies with different 
insect species, $\alpha$-glucosidase produced at least two (RAZAVI TABATABAEI et al. 2011) or three distinct bands (SILVA et al. 1999). Furthermore, in the midgut of many insect species there are three, four or even five digestive $\beta$-glucosidases (AZEVEDO et al. 2003).

Different types of glucosides are phytoanticipins, i.e. plant secondary compounds that occur widely in the plant kingdom (ZAGROBELNY et al. 2004, PANKOKE et al. 2010). Insect $\beta$-glucosidases are enzymes that catalyse the hydrolysis of broad range of aryl- and alkyl $\beta$-D-glucosides such as toxic glucosides, which have been identified as an elicitor in plant and herbivore interaction (WEI et al. 2007). In many cases, the aglycones usually produced by $\beta$-glucosidase activities are more toxic than the glycosides themselves (YU 1989). In this research, as a first step, some biochemical enzymatic properties of $\alpha$ - and $\beta$-glucosidase obtained from the midgut of $L$. decemlineata were determined. Therefore, identifying glucosides in different plants and studying their effects on $\beta$-glucosidase activity in pests such as the Colorado potato beetle in long term can be useful for producing a genotype resistant to this pest.

\section{REFERENCES}

Argentine J.A., Clark J.M., Ferro D. N. 1989. Genetics and synergism of resistance to azinphosmethyl and permethrin in the Colorado potato beetle (Coleoptera: Chrysomelidae). Journal of Economic Entomology 82(3): 698-705.

Azevedo T.M., Terra W.R., Ferreira C. 2003. Purification and characterization of three $\beta$-glycosidases from midgut of the sugar cane borer, Diathraea saccharalis. Insect Biochemistry and Molecular Biology 33(1): 81-92.

BAKER J.E. 1991. Properties of glycosidases from the maize weevil, Sitophilus zeamais. Insect Biochemistry 21(6): 615-621.

Bowers E.M., RAgland L.O., Byers L.D. 2007. Salt effects on beta-glucosidase: pH-profile narrowing. Biochimica et Biophysica Acta - Proteins Proteomics 1774(12): 1500-1507.

BRADFORD M. 1976. Rapid and sensitive method for quantitation of microgram quantities of protein utilizing the principle of protein dye binding. Analytical Biochemistry 72(1-2): 248-254.

Byeon G.M., Lee K.S., Gui Z.Z., Kim I., Kang P.D., Lee S.M., Sohn H.D., Jin B.R. 2005. A digestive beta glucosidase from the silkworm, Bombyx mori: cDNA cloning expression and enzymatic characterization. Comparative Biochemistry and Physiology 141(4): 418-427.

CAPINERA J.L. 2001. Handbook of vegetable pests. Academic Press, San Diego.

Carneiro N.B., Isejima E.M., SAmuels R.I., Silva C.P. 2004. Sucrose hydrolyses from the midgut of the sugarcane stalk borer Diatraea saccharalis. Journal of Insect Physiology 50(11): $1093-1101$.

ESEN A. (ed.) 1993. Beta-glucosidases: biochemistry and molecular biology. American Chemical Society, Washington. 
ESEN A. 1992. Purification and partial characterization of maize (Zea mays L.) $\beta$-glucosidase. Plant Physiology 98(1): 174-182.

ForGash A.J. 1985. Insecticide resistance in the Colorado potato beetle. [in:] D.N. FERRo, R.H. Voss (eds.). Proceedings of the symposium on the Colorado potato beetle, $17^{\text {th }}$ International Congress of Entomology. Massachusetts Experiment Station, University of Massachusetts, Amherst, $33-53$.

GaUthier N.L., Hofmaster R.N. Semel M. 1981. History of Colorado potato beetle control. [in:] J.H. LASHOMB, R. CASAGRANDE (eds.). Advances in potato pest management. Hutchinson Ross Publishing Co., Stroudsburg, 13-33.

GHAdAMYARI M., HosseininaveH V., Sharifi M. 2010. Partial biochemical characterization of $\alpha$ - and $\beta$-Glucosidases of Lesser mulberry pyralid, Glyphodes pyloalis WALKER (Lep.: Pyralidae). Comptes rendus biologies 333(3):197-204.

HARE J.D. 1990. Ecology and management of the Colorado potato beetle. Annual Review of Entomology 35: 81-100.

LAEMMLI U.K. 1970. Cleavage of structural proteins during the assembly of the bacteriophage T4. Nature 227(5259): 680-685.

Marana S.R., Terra W.R., Ferreira C. 1995. Midgut $\beta$-d-glucosidases from Abracris flavolineata (Orthoptera: Acrididae). Physical properties, substrate specificities and function. Insect Biochemistry and Molecular Biology 25(7): 835-843.

Marana S.R., Terra W.R., Ferreira C. 2000. Purification and properties of a beta-glucosidase purified from midgut cells of Spodoptera frugiperda (Lepidoptera) larvae. Insect Biochemistry and Molecular Biology 30(12): 1139-1146.

Mattiacci L.M., Dicke M., Posthumus M. A. 1995. $\beta$-Glucosidase: an elicitor of herbivore-induced plant odor that attracts host-searching parasitic wasps. Proceedings of the National Academy of Sciences of the United States of America 92(6): 2036-2040.

ONSTAD D. 2007. Insect resistance management: Biology, Economics and Prediction. Academic Press, San Diego.

Pankoke H., Bowersand M.D., Dobler S. 2010. Influence of iridoid glycoside containing host plants on midgut $\beta$-glucosidase activity in a polyphagous caterpillar, Spilosoma virginica FABRICIUS (Lep.: Arctiidae). Journal of Insect Physiology 56(12): 1907-1912.

PARRY M.W. 1996. A study of the interaction of some fungal metabolites with the insect species Drosophila melanogaster. Birkbeck College, University of London, London.

PONTOH J., LOw N.H. 2002. Purification and characterization of $\beta$-glucosidase from honeybees (Apis mellifera). Insect Biochemistry and Molecular Biology 32(6): 679-690.

Pratviel F., Clermont S., Percheron F., Chararas C. 1987. Studies on glycosidases and glucanases in Thaumetopoea pityocampa larvae. II. Purification and some properties of a broad specificity $\beta$-D-glucosidase. Comparative Biochemistry and Physiology Part B: Comparative Biochemistry 86(1): 173-178.

Price N.C., Stevens L. 1989. Fundamentals of Enzymology. Oxford University Press, Oxford.

RAmZi S., Hosseininaveh V. 2010. Biochemical characterization of digestive $\alpha$-amylase, $\alpha$-glucosidase and $\beta$-glucosidase in pistachio green stink bug, Brachynema germari KolENATI (Hemiptera: Pentatomidae). Journal of Asia-Pacific Entomology 13(3): 215-219. 
Razavi Tabatabaei P., Hosseininaveh V., Goldansaz S.H., Talebi K. 2011. Biochemical characterization of digestive proteases and carbohydrases of the carob moth, Ectomyelois ceratoniae (ZELLER) (Lepidoptera: Pyralidae). Journal of Asia-Pacific Entomology 14(2): $187-194$.

SANTOS C.D., TERRA W.R. 1984. Plasma membrane-associated amylase and trypsin: intracellular distribution of digestive enzymes in the midgut of the cassava hornworm, Erinnyis ello. Insect Biochemistry 14(5): 587-595.

Silva C.P., Terra W.R., Xavier-Filho J., Grossi De Sa M.F., Lopes A.R., Pontes E.G. 1999. Digestion in larvae of Callosobruchus maculates and Zabrotes subfasciatus (Coleoptera: Bruchidae) with emphasis on $\alpha$-amylases and oligosaccharidases. Insect Biochemistry and Molecular Biology 29(4): 355-366.

Souza-Neto J.A., Machado F.P. Lima J.B., Valle D., Ribolla P.E.M. 2007. Sugar digestion in mosquitoes: identification and characterization of three midgut Alpha-glucosidases of the Neotropical malaria vector Anopheles aquasalis (Diptera: Culicidae). Comparative Biochemistry and Physiology 147(4): 993-1000.

TERRA W.R., FerReIRA C. 1994. Insect digestive enzymes: properties, compartmentalization and function. Comparative Biochemistry and Physiology 109(1): 1-62.

Terra W.R., Ferreira C., Bastos F.1985. Phylogenetic considerations of insect digestion: Disaccharidases and the spatial organization of digestion in the Tenebrio molitor larvae. Insect Biochemistry 15(4): 443-449.

Terra W.R., Ferreira C., Garcia E.S. 1988. Origin, distribution, properties and functions of the major Rhodnius prolixus midgut hydrolases. Insect Biochemistry 18(5): 423-434.

Terra W.R., Ferreira C., Jordao B.P., Dillon R.J. 1996. Digestive enzymes. [in:] M.J. Lehane, P.F. Billingsley (eds.). Biology of the Insect Midgut. Chapman \& Hall, London, 86-114.

ToKuda G., SAito H., WatanaBe H. 2002. A digestive $\beta$-glucosidase from the salivary glands of the temite, Neotermes koshunensis (SHIRAKI): distribution, characterization and isolation of its precursor cDNA by 5'- and 3'-RACE amplifications with degenerate primers. Insect Biochemistry and Molecular Biology 32(12): 1681-1689.

Wei S.H., Semel Y., Bravdo B.A., Czosnek H., Shoseyov O. 2007. Expression and subcellular compartmentation of Aspergillus niger $\beta$-glucosidase in transgenic tobacco result in an increased insecticidal activity on whiteflies (Bemisia tabaci). Plant Science 172(6): 1175-1181.

YaPi D.Y.A., GnARKi D., Niamke S.L., KouAme L.P. 2009. Purification and biochemical characterization of a specific $\beta$-glucosidase from the digestive fluid of larvae of the palm weevil, Rhynchophorus palmarum. Journal of Insect Science 9: 4.

YU J. 1989. $\beta$-Glucosidase in four phytophagous Lepidoptera. Insect Biochemistry 19(1): 103-108.

Zagrobelny M., BaK S., Rasmussen A.V., Jorgensen B., Naumann C.M., Moller B.L. 2004. Cyanogenic glucosides and plant-insect interactions. Phytochemistry 65(3): 293-306.

Received: 21 June 2014

Accepted: 2 September 2014 